\title{
The Effect of Family Counseling on Anxiety, Depression, and Stress Levels in Mothers of Disabled Children: A Randomized Controlled Trial
}

\author{
Tarik Sari ${ }^{1}$, Memet Isık $^{2}$, Abdulkadir KAYA ${ }^{3}$, Zerrin Gamsizkan $^{2}$, and Elif Sari ${ }^{4}$ \\ ${ }^{1}$ Dereli Tütüncü Family Health Center \\ ${ }^{2}$ Duzce University \\ ${ }^{3}$ Duzce University Medical School \\ ${ }^{4}$ Private Düzce Bir Consultancy Center
}

April 10, 2021

\begin{abstract}
Objective: The aim of this study is to investigate the effect of family counseling on anxiety, depression, and stress levels in mothers with disabled children. Method: The research was conducted on the mothers of 80 randomly selected kids out of 200 disabled children studying at a Private Education and Rehabilitation Center. Six family counseling sessions were provided to the mothers in the study groups as eight participants per group. The primary outcomes of the study were changes in Beck Anxiety Inventory (BAI), Beck Depression Inventory (BDI), and Perceived Stress Scale (PSS) scores of the mothers at the beginning of the study; right after the counseling was finished, and three months later. The mean PSS, BDI, and BAI scores in the second tests performed right after the six counseling sessions were significantly lower than the average scores in the first tests $(\mathrm{p}<0.001, \mathrm{p}<0.001$, and $\mathrm{p}<0.001$, respectively). There was no significant difference between the 1st and 2nd PSS, BDI, and BAI mean scores of the mothers in the control group $(\mathrm{p}>0.05)$. Conclusion: Mothers of disabled children were exposed to anxiety, depression, and stress more than other society members. Thus, they need more psychological support. Family counseling can meet disabled children's mothers' support needs. The counseling program we applied had positive effects on mothers' anxiety, depression, and stress scores. By expanding this counseling service in primary health care services, mothers with disabled children can cope more easily with their psychological burden.
\end{abstract}

\section{Hosted file}

The Effect of Family Counseling on Anxiety, Depression, and Stress Levels in Mothers of Disabled Childr available at https://authorea.com/users/407004/articles/517453-the-effect-of-familycounseling-on-anxiety-depression-and-stress-levels-in-mothers-of-disabled-children-arandomized-controlled-trial

\section{Hosted file}

Table 1.pdf available at https://authorea.com/users/407004/articles/517453-the-effectof-family-counseling-on-anxiety-depression-and-stress-levels-in-mothers-of-disabledchildren-a-randomized-controlled-trial

\section{Hosted file}

Table 2.pdf available at https://authorea.com/users/407004/articles/517453-the-effectof-family-counseling-on-anxiety-depression-and-stress-levels-in-mothers-of-disabledchildren-a-randomized-controlled-trial 


\section{Hosted file}

Figure 1.pdf available at https://authorea.com/users/407004/articles/517453-the-effectof-family-counseling-on-anxiety-depression-and-stress-levels-in-mothers-of-disabledchildren-a-randomized-controlled-trial

\section{Hosted file}

Figure 2.pdf available at https://authorea.com/users/407004/articles/517453-the-effectof-family-counseling-on-anxiety-depression-and-stress-levels-in-mothers-of-disabledchildren-a-randomized-controlled-trial 